\title{
PREFERENSI MASYARAKAT TERHADAP LEMBAGA ZAKAT DAN BENTUK-BENTUK PEMBERDAYAAN DANA ZAKAT
}

\author{
Ahmad Mifdlol Muthohar \\ Institut Agama Islam Negeri (IAIN) Salatiga \\ mifdlol@gmail.com
}

\begin{abstract}
This study aims to find out the attitude of muzaki in handing over the zakat fund and their perspective of the zakat institution. This study used a qualitative approach, located in 13 cities. The research findings showed that according to muzaki, paying zakat to zakat institution is more ideal, however, they prefer to pay it with two different ways; first is to zakat institution and second is directly given to those who deserve to receive it. Muzaki prefer to pay their zakat to private zakat institutions rather than to those belong to government. Then Zakat funds should be managed by the institution of zakat. If the government manages the zakat, it should be fair and believable. Furthermore, muzaki are more satisfied when zakat institutions distribute the zakat to people around muzaki. It is for the Benefit of the most desired purpose that is educational, social, religious, economic empowerment and health.
\end{abstract}

Keywords: preference, muzaki, zakat institution,

\begin{abstract}
Abstrak
Penelitian ini bertujuan untuk mengetahui perilaku muzaki dalam penyerahan dana zakat dan persepsi mereka tentang lembaga zakat. Penelitian ini menggunakan pendekatan kualitatif, berlokasi di 13 kabupaten/kota. Hasil penelitian menunjukkan bahwa menurut muzaki, berzakat ke lembaga zakat tetap lebih ideal. Tetapi mereka lebih suka berzakat dengan dua model sekaligus, yaitu kepada lembaga zakat dan mustahik langsung. Selain itu muzaki memilih lembaga zakat swasta daripada pemerintah. Lalu dana zakat sebaiknya dikelola oleh satu lembaga zakat. Jika pemerintah yang mengelola, disyaratkan harus dapat bersikap adil dan amanah. Selanjutnya, muzaki lebih puas ketika lembaga zakat menyantuni warga sekitar muzaki. Adapun Santunan yang paling dikehendaki secara berurutan adalah pendidikan, sosial, keagamaan, pemberdayaan ekonomi dan kesehatan.
\end{abstract}

Kata Kunci: preferensi, muzaki, lembaga zakat

Permalink/DOI: http://dx.doi.org/10.18326/infsl3.v10i2.381-404 


\section{Pendahuluan}

Potensi dana zakat di Indonesia menurut kajian Asian Development Bank(ADB), mencapai Rp 100 triliun per tahun (Rama, 2010). Bahkan ada yang menyebutkan bahwa potensi zakat yang bisa dihimpun di Indonesia mencapai Rp 217 triliun per tahun, berdasarkan survei yang dilakukan BAZNAS, Institut Pertanian Bogor (IPB) dan Islamic Development Bank (IDB) pada 2011 (Republika, 19/8/2011).

Namun demikian, potensi tersebut masih belum terkelola dengan baik untuk kemanfaatan umat yang sebesar-besarnya. Masih banyak di antara muzaki yang tidak membayarkan zakatnya ke pemerintah melalui Badan Amil Zakat (BAZ) atau lembaga zakat swasta, melalui Lembaga Amil Zakat (LAZ).

Jika diperhatikan dengan seksama, polemik tentang model pembayaran zakat tersebut, memang sesuatu yang tidak disepakati oleh para ulama. Namun demikian sebagian pemikir ekonomi Islam telah menganggap itu sebagai sesuatu yang final, sebagaimana yang pernah ditulis oleh F. R. Faridi, yang mengupas tentang kemungkinan kebijakan fiskal negara berbasis zakat. Mayoritas negara-negara muslim gagal menerapkan kebijakan ini. Hal ini tidak terlepas dari polemik berkepanjangan yang mempengaruhi loyalitas setiap muslim dalam membayarkan zakatnya kepada pemerintah, sehingga mereka pun tidak dapat mengawasi secara optimal dan pemerintah muslim pun tidak dapat bekerja secara profesional (Faridi, 1976: 124). Semua target tersebut tidak mungkin berhasil tanpa adanya pengelolaan zakat secara bersama-sama dalam sebuah negara, baik itu oleh pemerintah maupun lainnya. Oleh karenanya, para muzaki pun juga berbeda-beda pengetahuan mereka tentang pembayaran zakat pada masa Rasulullah s.a.w. Mereka juga berselisih pendapat tentang persepsi seputar pembayaran zakat yang diambil, sehingga tak ayal jika perilaku mereka pun juga berbeda-beda.

Sejarah pelaksanaan zakat di Indonesia tidak terlepas dari kebijakan pemerintah Hindia Belanda masa lalu. Pemerintah Hindia Belanda memiliki kebijakan terhadap agama yang dicantumkan dalam beberapa pasal dari indisce Stastsregeling, di antaranya pada pasal 134 ayat 2 yang mengarah pada policy of religion neutrality, yaitu pelumpuhan syariat secara keseluruhan. Politik 
agama netral tersebut mengakibatkan Pemerintah Hindia Belanda tidak melakukan campur tangan dalam urusan agama, kecuali untuk suatu kepentingan (Inoed, 2005: 125-126). Maka wajar jika kemudian bermunculan lembaga-lembaga zakat swasta pada saat negara absen mengurusi masalah ini, yang disebabkan proses panjang pemberlakuan kebijakan pengelolaan zakat yang tidak boleh diurusi pemerintah. Itulah sebabnya mengapa di Indonesia kemudian ada dualisme pengelolaan zakat, yakni oleh pemerintah yang diwakili oleh Badan Amil Zakat (BAZ) dan oleh swasta, yang direpresentasikan oleh Lembaga Amil Zakat (LAZ) yang tidak hanya satu jumlahnya. Adapun terkait dengan lembaga zakat milik pemerintah atau swasta yang dianggap lebih professional, ini masih memerlukan pendalaman survei lapangan.

Penelitian yang dilakukan oleh Jaelani (2008) menunjukkan bahwa kualitas pelayanan berhubungan positif dengan keputusan muzaki dalam berzakat di Rumah Zakat Indonesia. Demikian pula penelitian yang dilakukan oleh Mus'ab (2012), menunjukkan bahwa terdapat pengaruh yang signifikan antara layanan terhadap minat masyarakat untuk membayar zakat maal di LAZIS NU. Demikian pula Muthohar (2015), dalam penelitiannya menyebutkan bahwa pelayanan lembaga zakat berpengaruh positif dan signifikan terhadap kecenderungan pilihan berzakat ke lembaga zakat. Hasil penelitian-penelitian menarik untuk dilakukan pendalaman lanjutan, terkait jenis lembaga zakat apa yang sesungguhnya diminati oleh para muzaki. Selain itu, juga perlu diteliti, Bagaimana pengetahuan muzaki tentang penyerahan zakat pada masa Rasulullah, persepsi mereka tentang penyerahan zakat yang ideal/afdhal, dan perilaku mereka dalam penyerahan dana zakat? Apa jenis lembaga zakat yang dipilih oleh responden di kawasan jalur Joglosemar? Siapakah pihak pengelola zakat yang tepat di Indonesia menurut muzaki? Bagaimanakah bentuk-bentuk layanan lembaga zakat yang dikehendaki muzaki?

Penelitian-penelitian optimalisasi pelayanan lembaga zakat tersebut sesungguhnya merupakan manifestasi dari kebijakan pemberlakuan pemungutan zakat yang telah turun temurun dilaksanakan semenjak zaman Rasulullah s.a.w. hingga saat ini. Salah satu bukti optimalisasi tersebut adalah ketika Imam Baihaqi 
meriwayatkan dari Imam Syafi'i, bahwa Abu Bakar dan 'Umar telah mengutus petugas untuk mengambil zakat. Bahkan Ibnu Sa'd menerangkan nama-nama petugas zakat itu dan nama suku-suku yang didatanginya. Dalam Shahih Bukhari-Muslim pula disebutkan, riwayat dari 'Umar bahwa ia telah mempekerjakan Ibnu Sa'di untuk menjadi petugas zakat. Dalam sebuah riwayat juga disebutkan bahwa 'Umar mengutus Sufyan bin Malik untuk memungut zakat dari warga (Abu Yusuf, [1979]: 82).

Syekh Zaruq telah menyebutkan bahwa tidak ada perbedaan di kalangan ulama bahwa zakat harus diserahkan secara sukarela kepada penguasa yang adil (Qardhawi, 1994 [2002]: 775). Yang menjadi polemik di antara mereka adalah ketika penguasa tersebut bertindak zalim. Dalam kondisi seperti itu, ada sebagian ulama yang membolehkan penyerahan zakat secara mutlak kepada mereka. Sedangkan yang lain tidak memperbolehkan.

Teori yang digunakan dalam penelitian ini adalah teori Clifford Geertz, yang menyatakan bahwa Geertz, tentang motivasi agama perlu ditambahkan. Geertz memberikan definisi tentang agama (religion) sebagai berikut (Geertz, 1973: 90): 1) Sebuah sistem simbol yang berperan; 2) Membangun suasana hati (kenyamanan) dan motivasi yang kuat, meresap dalam hati (pervasive) dan bertahan dalam diri manusia, dengan (melalui suatu cara/metode); 3) Merumuskan konsep tatanan kehidupan yang umum; 4) Mengemas konsep-konsep ini secara faktual; 5) Suasana hati dan motivasi tampak realistis secara unik.

Uraian Geertz di atas mengandung makna bahwa motivasi yang kuat salah satu cara atau metode yang dapat membangun suasana hati dan membentuk sebuah motivasi yang kuat. Hal itu dilakukan dengan melalui suatu cara/metode, yang dalam hal ini adalah melalui pemberian zakat oleh muzaki ke lembaga zakat. Sebagai seorang muslim, tentu akan lebih termotivasi, seandainya ia menunaikan zakatnya ke lembaga zakat. Bahkan menurut Geertz, suasana hati dan motivasi tersebut tidak hanya sekedar ada dalam hati, tetapi tampak realistis dan unik. Oleh karenanya, tidak mengherankan seandainya didapati banyak lembaga zakat, yayasan sosial, masjid ataupun mushalla, dan sejenisnya, yang kemudian 
mengelola zakat para muzaki, sebagai bentuk lahiriah dari suasana hati dan motivasi yang ada dalam diri seorang muzaki. Itulah bentuk keunikan dan realisasi dari motivasi kuat yang ada dalam diri seorang muzaki.

\section{Metode Penelitian}

Penelitian ini menggunakan pendekatan kualitatif. Teknik pengumpulan data dalam penelitian ini adalah dengan wawancara, observasi dan dokumentasi. Wawancara merupakan instrumen dalam bentuk tanya-jawab antara peneliti dengan responden untuk memperoleh suatu fakta atau data dengan melakukan komunikasi langsung dengan responden, baik berbicara secara langsung atau menggunakan teknologi komunikasi (Supardi, 2005: 121). Dalam penelitian ini, wawancara dipergunakan untuk memperjelas halhal yang belum diisi ataupun belum begitu jelas disebutkan dalam kuesioner. Wawancara dilaksanakan melalui dua tahap. Tahap pertama dilakukan terhadap 396 responden. Lalu dilanjutkan wawancara secara lebih mendalam pada tahap kedua, dengan responden yang berbeda, sejumlah 70 respoden. Wawancara secara mendalam perlu dilakukan, karena untuk menguak lebih rinci seputar bentuk-bentuk pemberdayaan dana zakat yang lebih disukai atau dikehendaki oleh para muzaki.

Observasi adalah instrumen pengumpulan data dengan cara mengamati objek yang diteliti, yang didukung dengan pengumpulan dan pencatatan data secara sistematis (Nasution, 1996: 10). Dalam penelitian ini observasi dipergunakan sebagai sumber data yang memberikan informasi tambahan tentang hal-hal yang terkait dengan zakat, terutama jika perlu pendalaman yang memerlukan kontak langsung secara fisik.

Dokumentasi adalah instrumen yang digunakan untuk mengumpulkan data-data dengan menelusuri berbagai jenis kepustakaan untuk memperoleh berbagai teori, konsep, dalil, pandangan para pakar terkait dan juga hasil penelitian terdahulu yang berhubungan dengan materi kajian serta data-data sekunder sebagai langkah awal kegiatan penelitian (Supardi, 2005: 61). 
Data dalam riset ini terdiri dari dua jenis; 1) Data primer yang berbasis riset lapangan; 2) Data sekunder yang berbasis library research. Data sekunder dipergunakan untuk mengungkap pendapatpendapat para pakar, ulama, baik klasik maupun kontemporer dan para nara sumber lain yang diperlukan.

Lokasi penelitian ini dalam penelitian ini meliputi kabupaten/ kota sepanjang jalur yang melewati Joglosemar (Yogyakarta, Surakarta dan Semarang). Adapun Kabupaten/Kota yang berada di jalur ini ada 13, yaitu: Yogyakarta, Klaten, Surakarta (Solo), Sukoharjo, Karanganyar, Boyolali, Salatiga, Kabupaten Semarang, Kota Semarang, Temanggung, Kabupaten Magelang, Kota Magelang dan Sleman. Adapun alasan pemilihan jalur Joglosemar sebagai obyek penelitian, karena jalur ini merupakan jalur bisnis terbesar di wilayah provinsi Jawa Tengah dan Yogyakarta, yang masyarakatnya merupakan masyarakat yang heterogen. Ada masyarakat kejawen, ningrat, moderat dan militan, perkotaan dan pedesaan, modern dan tradisional, masyarakat petani, pedagang/pengusaha dan pegawai dan karakter-karakter heterogen lainnya.

Sampel yang digunakan dalam penelitian ini adalah sampel jenis purposive random sampling, yaitu pengambilan sampel yang dalam hal ini peneliti menentukan batas-batas subyek yang dijadikan sebagai sampel penelitian. Adapun batas-batas tersebut sebagai berikut: 1) Responden yang membayar zakat pada lembaga zakat milik pemerintah, yang dalam hal ini adalah Badan Amil Zakat (BAZ) atau lembaga zakat milik nonpemerintah, yang dalam hal ini adalah Lembaga Amil Zakat (LAZ); 2) Responden yang membayar zakat pada BAZ/LAZ dan juga kepada mustahik secara langsung; 3) Responden yang membayar zakat kepada mustahik secara langsung; 4) Responden yang membayar zakat kepada amil zakat di masjid atau mushalla; 5) Responden yang membayar zakat kepada lembaga zakat selain BAZ/LAZ dan masjid/mushalla.

Pengetahuan, Persepsi dan Perilaku Muzaki Seputar Penyerahan Zakat

Ada data menarik yang dapat dilihat di dalam tabel hasil jawaban angket yang ditulis oleh 396 responden (muzaki) berikut ini: 
Tabel 1.

Pengetahuan, Persepsi dan Perilaku Muzaki Seputar Penyerahan Zakat

\begin{tabular}{|c|c|c|c|c|c|}
\hline No & $\begin{array}{c}\text { Item } \\
\text { Permasalahan } \\
\text { Zakat }\end{array}$ & $\begin{array}{c}\text { Ke } \\
\text { Lembaga } \\
\text { Zakat (LZ) }\end{array}$ & $\begin{array}{c}\text { Ke } \\
\text { Mustahik } \\
\text { Langsung }\end{array}$ & $\begin{array}{c}\text { Ke LZ \& } \\
\text { Mustahik }\end{array}$ & Lainnya \\
\hline 1 & $\begin{array}{l}\text { Pengetahuan } \\
\text { muzaki tentang } \\
\text { penyerahan } \\
\text { zakat pada masa } \\
\text { Rasul s.a.w. }\end{array}$ & $130(33 \%)$ & $\begin{array}{l}74 \\
(19 \%)\end{array}$ & $\begin{array}{l}131 \\
(33 \%)\end{array}$ & $61(16 \%)$ \\
\hline 2 & $\begin{array}{l}\text { Persepsi } \\
\text { muzaki tentang } \\
\text { penyerahan } \\
\text { zakat yang afdhal } \\
\text { (ideal). }\end{array}$ & $110(28 \%)$ & $\begin{array}{l}36 \\
(9 \%)\end{array}$ & $\begin{array}{l}231 \\
(58 \%)\end{array}$ & $19(5 \%)$ \\
\hline 3 & $\begin{array}{l}\text { Perilaku } \\
\text { muzaki dalam } \\
\text { penyerahan } \\
\text { zakat. }\end{array}$ & $109(27 \%)$ & $\begin{array}{l}74 \\
(19 \%)\end{array}$ & $\begin{array}{l}213 \\
(54 \%)\end{array}$ & - \\
\hline
\end{tabular}

Sumber: Data primer diolah

Dari data tersebut dapat disimpulkan bahwa secara umum prospek lembaga zakat akan cenderung lebih baik di masa mendatang. Hal ini dapat dilihat dari pengetahuan muzaki tentang penyerahan zakat kaum muslimin pada masa Rasulullah s.a.w. yang cenderung lebih banyak menyatakan bahwa zakat pada masa Rasulullah s.a.w. itu diserahkan kepada pemerintah, yang pada masa sekarang itu dapat terwakili oleh lembaga zakat. Pengetahuan tersebut tidak jauh berbeda dengan persepsi mereka. Menurut persepsi para muzaki, berzakat ke lembaga zakat tetap lebih afdhal dan lebih ideal. Namun demikian perilaku mereka menunjukkan bahwa yang mereka sukai adalah berzakat ke dua-duanya, lembaga zakat dan mustahik langsung. Bahkan angka perilaku memilih dua-duanya ini cukup besar, yakni 54 $\%$. Ini menunjukkan perilaku para muzaki yang cenderung moderat, mengambil jalan keluar win-win solution. 
Pengetahuan muzaki tentang pola pembayaran zakat pada masa Rasul s.a.w., persepsi mereka tentang pembayaran zakat ideal dan perilaku mereka dalam berzakat, semuanya mengarah kepada satu pemikiran, bahwa lembaga zakat tetap terbaik sebagai objek pembayaran dana zakat. Namun demikian mayoritas muzaki lebih memilih jalan tengah dalam perilaku mereka, yaitu membayarkan dana zakat ke lembaga zakat dan di satu waktu sekaligus juga ke mustahik langsung.

\section{Jenis Lembaga Zakat Pilihan}

Dari data penelitian sebelumnya, ditemukan bahwa pelayanan lembaga zakat berpengaruh signifikan terhadap kecenderungan pilihan muzaki dalam berzakat ke lembaga zakat di kawasan Joglosemar. Artinya secara umum muzaki di kawasan Joglosemar menganggap bahwa pelayanan lembaga zakat menjadi faktor pendorong mereka dalam memberikan kecenderungan pilihannya ke lembaga zakat. Nilai koefisien regresi pelayanan lembaga zakat cukup tinggi, yaitu 9,84. Pelayanan lembaga zakat di sini meliputi beberapa dimensi yang dijadikan sebagai tolok ukur, yaitu akuntabilitas, transparansi, profesionalitas, aksestabilitas, lokasi, komunikasi dan popularitas. Namun dimensi-dimensi tersebut dijadikan sebagai satu variabel, yaitu variabel pelayanan lembaga zakat (Muthohar, 2015: 204-205).

Penelitian yang dilakukan oleh Syaparuddin juga menunjukkan bahwa di antara dimensi yang merupakan salah satu aspek dari pelayanan lembaga zakat, ada yang berpengaruh secara signifikan terhadap besarnya zakat para muzaki ke lembaga zakat. Dimensi tersebut adalah aksestabilitas. Dalam hal ini ada perbedaan metode yang dipergunakan dalam melihat masalah ini. Syaparudin menjadikan dimensi aksestabilitas sebagai sebuah variabel independen, sedangkan dalam penelitian ini hanya sekadar menjadi salah satu indikator dalam variabel pelayanan lembaga zakat. Artinya dalam penelitian ini aksestabilitas hanyalah satu dari tujuh indikator yang membentuk sebuah variabel, yaitu variabel pelayanan lembaga zakat (Syaparuddin, 2011). 
Dari data penelitian 396 responden, yang memberikan zakatnya hanya ke lembaga zakat ada 74 muzaki (18,69\%). Sedangkan yang memberikan zakatnya ke lembaga zakat dan juga ke mustahik langsung (dengan pembagian persentase yang berbeda) ada 213 responden (53,79\%). Dan terakhir yang menyerahkan zakatnya hanya ke mustahik ada 109 responden (27,53 \%). Jadi, secara keseluruhan muzaki yang menyerahkan zakatnya ke lembaga zakat ada 287 orang. Dari 287 orang tersebut (72,47\%), ditemukan data jenis lembaga zakat kecenderungan pilihan muzaki sebagai berikut:

Tabel 2.

\section{Jenis Lembaga Zakat Pilihan Muzaki (Jika Pilihan Hanya 1)}

\begin{tabular}{llll}
\hline No & Jenis Lembaga Zakat & Jumlah Muzaki & Persentase \\
\hline 1 & LZ Swasta & 165 & $57 \%$ \\
2 & LZ Pemerintah & 39 & $14 \%$ \\
3 & Masjid & 22 & $8 \%$ \\
4 & Tidak menjawab & 61 & $21 \%$ \\
Total & & 287 & $100 \%$ \\
\hline
\end{tabular}

\section{Sumber: Data Primer Diolah}

Dari data di atas, terlihat bagaimana kecenderungan muzaki lebih tertuju kepada lembaga zakat milik swasta dibandingkan lembaga zakat milik pemerintah, yakni sebesar 165 muzaki (57 \%). Padahal itu dengan asumsi muzaki yang menyerahkan zakat ke masjid dikategorikan dalam kelompok tersendiri. Seandainya masjid juga dianggap sebagai lembaga zakat milik swasta, maka secara keseluruhan ada 187 muzaki (65 \%) yang berzakat ke lembaga zakat swasta, dari total responden yang berjumlah 287 orang. Sedangkan yang berzakat ke lembaga zakat milik pemerintah hanya 39 orang (14\%). Dan sebanyak 61 responden (21\%) tidak menjawab.

Dari data tersebut, pelayanan lembaga zakat yang signifikan berpengaruh terhadap kecenderungan pilihan muzaki dalam berzakat ke lembaga zakat, sesungguhnya didominasi 
oleh lembaga zakat swasta. Oleh karenanya, saat ini belum tepat waktunya jika ada upaya dari pemerintah untuk menyatukan manajemen zakat menjadi satu dan dikelola pemerintah. Opini publik masih belum dapat dilepaskan dari kepercayaan terhadap lembaga zakat swasta, dibandingkan terhadap lembaga zakat pemerintah. Data tersebut adalah data sendainya responden muzaki diberi pilihan menjawab satu jenis lembaga zakat.

Selanjutnya apabila responden muzaki diberikan pilihan lebih dari satu lembaga zakat, maka kecenderungan pilihan mereka adalah sebagai berikut:

Tabel 3.

Jenis Lembaga Zakat Pilihan Muzaki (Jika Pilihan > 1)

\begin{tabular}{llll}
\hline No & Jenis Lembaga Zakat & Jumlah Muzaki & Persentase \\
\hline 1 & LZ Swasta & 179 & $58 \%$ \\
2 & LZ Pemerintah & 39 & $13 \%$ \\
3 & Masjid & 26 & $8 \%$ \\
4 & Tidak menjawab & 62 & $20 \%$ \\
Total & & 306 & $100 \%$ \\
\hline
\end{tabular}

Sumber: Data Primer Diolah

Dari data tersebut, ada sedikit perbedaan dari sebelumnya. Jika sebelumnya responden diberikan hanya satu pilihan lembaga zakat-yaitu pilihan pertama, sedangkan data di atas memberikan pilihan kepada responden lebih dari satu pilihan, sehingga total jawaban responden yang sebelumnya hanya 287 lembaga zakat, bertambah menjadi 306 lembaga zakat. Dari 306 lembaga zakat pilihan muzaki, ternyata yang mengalami pertambahan adalah lembaga zakat swasta, yaitu sebesar 14 pilihan (1 \%). Adapun lembaga zakat pemerintah masih stagnan, yaitu 39 pilihan. Artinya seandainya responden yang berzakat ke lembaga zakat diberikan pilihan lebih dari satu untuk menyebutkan lembaga zakat yang menjadi pilihan mereka, tidak ada satu pun dari mereka yang 
menjadikan lembaga zakat pemerintah sebagai pilihan alternatif. Padahal jika dicermati, baik lembaga zakat pemerintah maupun swasta sama-sama memiliki jangkauan yang lebih luas sampai ke tingkat kecamatan, karena masjid dan yayasan sosial diasumsikan masuk ke dalam kategori lembaga zakat swasta.

Walaupun upaya pengumpulan zakat oleh pemerintah saja -tanpa lembaga zakat lain- tersebut baik dan dipraktikkan di banyak negara muslim selain Indonesia, namun khusus di Indonesia hal itu belum dapat dilakukan dengan serta-merta. Perlu ada upaya jalan tengah untuk menuju ke sana, misalnya seperti gagasan yang pernah dilontarkan oleh M. Sabeth Abilawa, bahwa zakat sudah harus memasuki Gelombang Ketiga peradabannya, di mana Lembaga Zakat milik swasta seharusnya mengambil peran sebagai mitra pemerintah dalam memandirikan umat melalui advokasi kebijakan untuk menciptakan keadilan sosial. Tidak hanya sekedar berkutat pada penyaluran secara produktif, yang nominalnya tidak seberapa. Bukan dilebur menjadi satu di bawah pemerintah semuanya (Abilawa, 2010). Mitra pemerintah yang dimaksud di sini tentu tidak hanya sekedar sebagai pengambil kebijakan yang kurang begitu aktif, sebagaimana yang dapat dipahami dari UU nomor 23 Tahun 2011 tentang pengelolaan zakat. Namun harus dapat duduk bersama secara sejajar antara lembaga zakat swasta dan lembaga zakat pemerintah.

\section{Pihak Pengelola Zakat yang Tepat}

Kesimpulan tersebut tidak bertentangan dengan solusi yang ditawarkan oleh para muzaki tentang pengelolaan zakat di Indonesia, yang menurut mayoritas dari mereka sebaiknya dikelola oleh satu lembaga zakat, hanya saja mereka tidak memilih apakah itu lembaga zakat swasta atau lembaga zakat pemerintah. Berikut rincian solusi yang mereka tawarkan untuk pengelolaan zakat di Indonesia: 
Tabel 4.

Solusi Pengelolaan Zakat di Indonesia

\begin{tabular}{|c|c|c|c|}
\hline No & Solusi Tawaran Pengelolaan Zakat: & Jumlah & $\%$ \\
\hline 1 & Satu pengelola: Pemerintah & 35 & $9 \%$ \\
\hline 2 & $\begin{array}{l}\text { Satu pengelola: Swasta (termasuk masjid/ } \\
\text { mushalla) }\end{array}$ & 46 & $12 \%$ \\
\hline 3 & Satu pengelola: (tidak disebutkan) & 182 & $46 \%$ \\
\hline 4 & Banyak pengelola: (tidak disebutkan) & 105 & $27 \%$ \\
\hline 5 & Mustahik langsung & 7 & $2 \%$ \\
\hline 6 & Lainnya & 21 & $5 \%$ \\
\hline \multicolumn{2}{|c|}{ Jumlah } & 396 & $100 \%$ \\
\hline
\end{tabular}

Sumber: Data primer diolah

Memang dari data di atas dapat dikatakan bahwa kecenderungan muzaki lebih banyak memilih zakatnya dikelola oleh swasta (12\%), daripada pemerintah (9\%), namun pautan nilainya tidak begitu besar. Adapun kecenderungan mayoritas dari mereka tertuju pada pengelolaan zakat yang terfokus menjadi satu, hanya saja mereka tidak menentukan apakah itu dikelola pemerintah atau swasta.

Namun demikian, apabila pertanyaan untuk mereka diarahkan pada pengelolaan oleh pemerintah, hasilnya ternyata positif. Dari hasil wawancara terhadap 396 responden, secara umum mereka tidak menolak jika pemerintah yang mengelola zakat, dengan catatan pemerintah bersikap adil dan amanah. Responden yang mensyaratkan pemerintah harus adil dan amanah dalam pengelolaan dana zakat ada 339 orang (85\%). Sebagian reponden ada yang memilih tidak harus ada syarat adil, boleh juga pemerintah zalim memungut dana zakat. Mereka berjumlah 21 orang (5\%). Sebagian yang lain ada yang tidak memilih pembayaran dana zakat kepada tatanan pemerintah yang ada saat ini, akan tetapi lebih memilih diberikan kepada lembaga apa saja, pemerintah 
maupun nonpemerintah, dengan syarat adil dan amanah. Mereka ini berjumlah 4 orang (1\%). Sebagian yang lain memilih lembaga swasta yang adil dan amanah, yaitu 12 orang (3\%). Ada pula yang siap memberikan kepada pemerintah akan tetapi pemerintah Islam, yaitu 5 responden (1\%). 1 responden (0,3\%) lebih memilih untuk memberikan dana zakat langsung kepada mustahik. Dan terakhir ada sebanyak 14 responden ( $4 \%$ ) yang tidak menjawab pertanyaan. Berikut rincian dari pilihan responden muzaki terhadap pembayaran dana zakat kepada pemerintah:

Tabel 5.

Penyerahan Zakat Responden Muzaki kepada Pemerintah

\begin{tabular}{|c|c|c|c|}
\hline No & Penyerahan Zakat pada Pemerintah & Jumlah & Persentase \\
\hline 1 & Apabila pemerintah adil dan amanah & 339 & $85 \%$ \\
\hline 2 & $\begin{array}{l}\text { Adil/Zalim tetap diserahkan } \\
\text { pemerintah }\end{array}$ & 21 & $5 \%$ \\
\hline 3 & Nonpemerintah yang amanah & 12 & $3 \%$ \\
\hline 4 & $\begin{array}{l}\text { Lembaga apapun yang adil dan } \\
\text { amanah }\end{array}$ & 4 & $1 \%$ \\
\hline 5 & Pemerintah Islam & 5 & $1 \%$ \\
\hline 6 & Langsung Mustahik & 1 & $0,3 \%$ \\
\hline 7 & Tidak menjawab & 14 & $4 \%$ \\
\hline \multicolumn{2}{|c|}{ Jumlah } & 396 & $100 \%$ \\
\hline
\end{tabular}

Sumber: Data primer diolah

Dari data di atas, mayoritas muzaki masih berharap pemerintah mengelola zakat, namun dengan syarat memiliki sifat adil dan amanah. Artinya masih ada harapan bagi pemerintah untuk memperbaiki manajemen kinerja pengelolaan zakat secara kredibel yang berbasis adil dan amanah. Menurut Bisri (2012), kelemahan utama manajemen zakat di Indonesia adalah aspek kelembagaannya. Sistem manajemen zakat belum terbentuk, karena regulasinya belum lengkap. Institusi pengelola zakat yang 
terpusat pada Baznas, sesuai prinsip yang terintegrasi, sebagaimana kehendak UU, juga belum merata. Di samping itu, strukturnya juga masih belum lengkap. Bahkan diyakini, kebanyakan muzaki masih membayar zakatnya melalui LAZ yang dibentuk masyarakat atau langsung kepada mustahik.

\section{Bentuk-bentuk Pelayanan Lembaga Zakat}

Dari pendalaman yang dilakukan terhadap 70 muzaki yang berzakat di lembaga zakat, baik LAZ resmi, maupun LAZ mushalla/ masjid, 49 di antara mereka mengatakan bahwa salah satu hal yang menyebabkan mereka berzakat di lembaga zakat tertentu, karena lembaga zakat tersebut menyantuni warga tidak mampu di sekitar muzaki tadi. Artinya, muzaki memahami bahwa keberkahan berzakat akan lebih mereka rasakan tatkala lembaga zakat tersebut menyantuni warga tidak mampu di sekitar muzaki tadi. Para muzaki akan merasa lebih puas terhadap kinerja lembaga zakat, seandainya lembaga zakat dapat menyantuni warga tidak mampu di sekitar muzaki. Warga tidak mampu tersebut bisa merupakan fakir miskin, yatim piatu, orang tua jompo, anak-anak kurang mampu yang memerlukan beasiswa pendidikan, dan lain sebagainya (wawancara 70 responden, 2014). Bentuk layanan tersebut dapat dilihat dalam tabel berikut ini:

\section{Tabel 6.}

\section{Bentuk Layanan Lembaga Zakat terhadap Warga Sekitar Domisili Muzaki}

\begin{tabular}{llll}
\hline No & Bentuk Layanan Lembaga Zakat & Frek & \% \\
\hline $\mathbf{1}$ & Keagamaan: & $\mathbf{1 9}$ & $\mathbf{2 2}$ \\
& $\begin{array}{l}\text { a. Pengajian umum } \\
\text { b. Penanggulangan upaya Kristenisasi }\end{array}$ & 4 & 5 \\
$\begin{array}{l}\text { c. Pengadaan buletin/majalah islami, buku qira'ati } \\
\text { dan perpustakaan keliling }\end{array}$ & 4 & 5 \\
d. Pelatihan takmir masjid & 2 & 2
\end{tabular}


e. Perbaikan tempat ibadah (tempat wudlu, dll) $6 \quad 7$

\begin{tabular}{|c|c|c|c|}
\hline \multirow[t]{2}{*}{2} & Pendidikan: & 30 & 34 \\
\hline & $\begin{array}{l}\text { a. Pendidikan formal (beasiswa buat murid SD, } \\
\text { SMP, SM, mahasiswa dan honor guru) } \\
\text { b. Pendidikan nonformal (pondok pesantren, } \\
\text { TPA/TPQ) }\end{array}$ & 11 & 12 \\
\hline \multirow[t]{6}{*}{3} & Sosial: & 25 & 28 \\
\hline & $\begin{array}{l}\text { a. Santunan fakir miskin, } \\
\text { pengangguran dan tuna wisma atau rumah } \\
\text { belum layak huni }\end{array}$ & 17 & 20 \\
\hline & b. Santunan buat anak yatim (beasiswa dll) & 3 & 3 \\
\hline & $\begin{array}{l}\text { c. Sarana prasarana pemakaman (pembuatan } \\
\text { keranda mayat dan honor penggali kubur) }\end{array}$ & 2 & 2 \\
\hline & $\begin{array}{l}\text { d. Bakti sosial (dalam bentuk pasar murah, } \\
\text { dll) }\end{array}$ & 2 & 2 \\
\hline & e. Khitanan masal & 1 & 1 \\
\hline \multirow[t]{5}{*}{4} & Kesehatan: & 6 & 7 \\
\hline & a. Bantuan air bersih & 1 & 1 \\
\hline & $\begin{array}{l}\text { b. Pusat kesehatan keliling } \\
\text { (puskesling) }\end{array}$ & 1 & 1 \\
\hline & c. Pengobatan gratis & 3 & 4 \\
\hline & d. Penambahan gizi masyarakat & 1 & 1 \\
\hline \multirow[t]{6}{*}{5} & Pemberdayaan Ekonomi: & 8 & 9 \\
\hline & a. Pembuatan kompor minyak & 1 & 1 \\
\hline & b. Pembuatan tempat sampah dari ban bekas & & \\
\hline & $\begin{array}{l}\text { c. Pemberian modal berbentuk sapi perah, } \\
\text { kambing dan ayam, secara bergulir }\end{array}$ & 4 & 5 \\
\hline & $\begin{array}{l}\text { d. Fasilitasi pengusaha kecil, melalui forum } \\
\text { bersama atau forum pengajian interaktif }\end{array}$ & 3 & 3 \\
\hline & Total & 88 & 100 \\
\hline
\end{tabular}

Sumber: Data primer diolah 
Dari data tersebut menunjukkan bahwa muzaki yang berzakat di lembaga zakat, lebih merasakan keberkahan ketika lembaga zakat tersebut menyantuni warga di sekitar tempat tinggal atau kantor muzaki. Karenanya, jika selama ini banyak muzaki yang mengalokasikan dananya ke mustahik langsung, maka itu adalah koreksi buat lembaga-lembaga zakat yang ada, khususnya terkait dengan distribusi zakat kepada warga, sebagai objek santunan. Santunan yang paling banyak dan sering dilihat secara langsung oleh muzaki adalah santunan pendidikan (34\%), lalu santunan sosial (28\%), keagamaan (22 \%), pemberdayaan ekonomi (9\%) dan kesehatan (7\%).

Dari data tersebut di atas, santunan pendidikan menduduki mayoritas kebutuhan kaum muslimin. Hal itu sesuai dengan kondisi riil pendidikan di Indonesia akhir-akhir ini. Menurut Education for All Global Monitoring Report 2012 yang dikeluarkan oleh UNESCO setiap tahunnya, pendidikan Indonesia berada di peringkat ke-64 untuk pendidikan di seluruh dunia dari 120 negara. Data tersebut relatif lebih baik dibandingkan pada tahun sebelumnya (2011), di mana Indonesia berada pada peringkat ke-69 dari 127 negara (Harahap, 2013). Data tersebut diperkuat oleh data yang dikeluarkan oleh Kemendikbud Tahun 2010, bahwa di Indonesia terdapat lebih dari 1,8 juta anak tiap tahun tidak dapat melanjutkan pendidikan, disebabkan oleh tiga faktor, yaitu ekonomi, kerja usia dini untuk mendukung keluarga dan pernikahan di usia dini. Demikian pernyataan Sekretaris Direktorat Jenderal Perguruan Tinggi, Patdono Suwignjo (Harahap, 2013).

Kemudian ada sebanyak 21 muzaki yang mengatakan bahwa mereka berzakat ke lembaga zakat tertentu, bukan karena lembaga zakat tersebut menyantuni warga tidak mampu di sekitarnya. Walaupun demikian, 21 orang ini memiliki santunansantunan khusus, baik dari dana zakat maupun sedekah, yang dapat disimpulkan bahwa pada prinsipnya mereka tetap memprioritaskan tetangga dan warga sekitar rumah. 
Dari 21 muzaki di atas, 12 di antara mereka ternyata adalah orang-orang yang telah mengalokasikan dana khusus yang berasal dari zakat, untuk menyantuni warga kurang mampu di sekitar lingkungannya (wawancara 24/2/14 s.d. 22/4/14). Sedangkan 7 orang muzaki di antara mereka, ada alokasi dana tertentu dari sedekah, untuk warga atau lingkungan sekitarnya yang membutuhkan (wawancara 24/2/14 s.d. 22/4/14). Sedangkan 2 orang muzaki lainnya tidak memberikan jawaban secara tegas tentang keberadaan dana sedekah khusus untuk warga atau lingkungan di sekitar tempat tinggal. Dengan demikian, dengan melalui dana sedekah buat warga sekitar tadi, mereka dapat dengan leluasa dalam menyantuni warga di sekitar lingkungannya, dan oleh karenanya, tidak perlu mengandalkan santunan dari lembaga zakat.

Berikut ini merupakan tabel dua kelompok muzaki yang berzakat di lembaga zakat:

\section{Tabel 7.}

\section{Dua Kelompok Muzaki yang Berzakat di Lembaga Zakat}

\begin{tabular}{cccc}
\hline No & \multicolumn{1}{c}{ Kelompok Muzakki } & Jumlah & Persentase \\
\hline & $\begin{array}{l}\text { Kelompok I; yang berargumen } \\
\text { bahwa dirinya berzakat ke lembaga } \\
\text { zakat, karena lembaga zakat telah } \\
\text { menyantuni warga di sekitar muzaki }\end{array}$ & 49 muzaki & $70 \%$ \\
& $\begin{array}{l}\text { Kelompok II; yang berargumen } \\
\text { bahwa dirinya berzakat ke lembaga } \\
\text { zakat, bukan karena lembaga zakat } \\
\text { menyantuni warga di sekitarnya }\end{array}$ & 21 muzaki & $30 \%$ \\
\hline & Total & $100 \%$ \\
\hline
\end{tabular}

\section{Sumber: Data primer diolah}

Rincian kelompok II yang berzakat ke lembaga zakat, bukan karena santunan yang diberikan lembaga zakat tersebut kepada warga di sekitar muzaki, sebagai berikut: 
Tabel 8.

Rincian Muzaki Kelompok II

\begin{tabular}{llcc}
\hline No & Kelompok Muzaki & Jumlah & Persentase \\
\hline 1 & $\begin{array}{l}\text { Memiliki alokasi khusus untuk warga } \\
\text { sekitar muzaki, dari dana zakat }\end{array}$ & 12 & $57 \%$ \\
2 & $\begin{array}{l}\text { Memiliki alokasi khusus untuk warga } \\
\text { sekitar muzaki, dari dana sedekah } \\
\text { (selain zakat) }\end{array}$ & 7 & $33 \%$ \\
\hline $\begin{array}{l}\text { Tidak memberikan jawaban secara } \\
\text { tegas tentang keberadaan dana khusus } \\
\text { untuk warga sekitar } \\
\text { Total }\end{array}$ & 2 & $10 \%$ \\
\hline
\end{tabular}

Sumber: Data primer diolah

Muzaki kelompok II yang memiliki alokasi dana secara khusus dari dana zakat, untuk warga sekitarnya, persentase zakat yang mereka tunaikan antara yang diberikan kepada lembaga zakat dan yang diberikan kepada mustahik langsung, sebagai berikut:

Tabel 9.

Persentase Dana Zakat Muzaki Kelompok II

\begin{tabular}{llll}
\hline No & Nama & Ke Lembaga Zakat & Ke Mustahik Langsung \\
\hline 1 & Noor Utami & $10 \%$ & $90 \%$ \\
2 & Bambang & $20 \%$ & $80 \%$ \\
3 & Aqni Hanifah & $25 \%$ & $75 \%$ \\
4 & Ifonilla Y & $0 \%$ & $100 \%$ \\
5 & samino & $10 \%$ & $90 \%$ \\
6 & Lutfi & $50 \%$ & $50 \%$ \\
7 & Agus & $50 \%$ & $50 \%$ \\
8 & Wasdi & $50 \%$ & $50 \%$
\end{tabular}




\begin{tabular}{lll}
$9 \quad$ Sadha & $70 \%$ & $30 \%$ \\
$10 \quad$ Fulan & $50 \%$ & $50 \%$ \\
Nilai Rerata & $33,5 \%$ & $66,5 \%$ \\
\hline
\end{tabular}

Sumber: Data primer diolah

Data di atas menunjukkan bahwa persentase dana zakat mereka, sebagian besar diberikan kepada mustahik langsung. Jadi walaupun 10 orang muzaki di atas mengaku bahwa mereka berzakat ke lembaga zakat bukan karena lembaga zakat tersebut menyantuni warga di sekitar mereka, namun ternyata dana zakat yang diberikan kepada lembaga zakat tersebut hanyalah kecil persentasenya. Sedangkan persentase yang besar justru mereka berikan kepada mustahik langsung. Hal itu menunjukkan bahwa betapapun mereka menyatakan bahwa berzakat ke lembaga zakat, bukan karena motif bahwa lembaga zakat tersebut menyantuni warga di sekitarnya, namun ternyata mereka sendiri sesungguhnya menyatakan secara implisit bahwa menyantuni warga sekitar itu sangatlah penting, bahkan lebih penting daripada berzakat ke lembaga zakat sendiri. Demikian kesimpulan ketika melihat tabel 27 persentase dana zakat muzaki kelompok II di atas.

Selanjutnya muzaki kelompok II yang mengalokasikan dana dari dana sedekah atau selain dana zakat, berjumlah 7 orang. Mereka adalah Helmi, Wiwik, Basith, Yan Surono, Nisa' Puspitasari, Muharyati, dan Juz'an. Dari tujuh orang tersebut ada 3 orang yang diwawancarai secara lebih mendalam terkait dengan hal ini. Mereka adalah Helmi, Wiwik dan Basith.

Helmi mengaku telah mengalokasikan dana untuk warga sekitar dan diserahkan kepada takmir masjid Nuruz Zahrah yang memiliki program Badan Kesejahteraan Masjid (BKM). Helmi menyatakan bahwa dana ini murni dari dana sedekah, bukan dana zakat (Helmi, 24/2/2014).

Wiwik yang memiliki toko swalayan, meskipun ia mengatakan bahwa dirinya berzakat ke lembaga zakat bukan karena peran lembaga zakat tersebut dalam menyantuni warga sekitar, ternyata beliau juga memiliki dana khusus hingga $20 \%$ dari penghasilan, yang diperuntukkan buat infak dan sedekah. $\mathrm{Bu}$ Wiwik ini merupakan pengagum Ustadz Yusuf Manshur dalam 
konsepnya tentang sedekah. Alokasi dana yang ia keluarkan selama ini dibagi menjadi 3; Pertama yang dikeluarkan per tahun sekali atas nama zakat, yang ia berikan ke LAZIS MU, DSH, dan Panti-panti asuhan. Kedua, dana sedekah yang dikeluarkan perbulan, yaitu ke anak yatim di Kecamatan Juwiring (Klaten) dan Klaten kota (Wiwik, 28/2/2014). Selanjutnya Basith mengaku bahwa selama ini ia telah mengalokasikan dana tertentu untuk menyantuni warga sekitarnya melalui paket-paket sembako, bahkan tidak hanya berasal dari dananya sendiri, akan tetapi ia juga melibatkan beberapa famili untuk santunan tersebut (Basith, 2/3/2014).

Dari data beberapa muzaki kelompok II yang diwawancarai tadi, semuanya menguatkan bahwa faktor santunan terhadap warga sekitar muzaki berada, itu sangatlah penting. Selain 7 muzaki dari kelompok II tersebut, ada lagi 2 orang yang tidak menentukan sikap secara terang-terangan, apakah ia memiliki alokasi dana zakat atau sedekah buat warga sekitarnya. Mereka adalah Sofyan dan Madiyo. Namun demikian dari penuturan Sofyan, sesungguhnya dapat disimpulkan bahwa ia sesungguhnya juga menganggap penting adanya alokasi dana khusus buat warga sekitarnya. Sofyan mengaku bahwa karena kesibukannya, ia tidak mengetahui santunan/layanan yang diberikan lembaga zakat Dompet Sejuta Harapan (DSH) di Klaten. Tetapi Sofyan mengaku ada beberapa program yang ia ajukan ke DSH dan kemudian dilaksanakan oleh DSH, yaitu: a) program santunan untuk anak yatim di kampung; b) program pemberantasan buta huruf Al-qur'an, melalui Tim DSH yang didatangkan (Sofyan, 26/2/2014). Jadi meskipun Sofyan mengaku berzakat ke lembaga zakat bukan karena santunan yang diberikan lembaga zakat kepada warga sekitarnya, namun ternyata Sofyan sendiri menganggap penting adanya santunan tersebut kepada warga di sekitarnya.

Berbeda dengan Madiyo yang mengaku berzakat ke lembaga zakat juga bukan karena lembaga zakat tersebut menyantuni warga sekitar, namun ia kebingungan membedakan antara zakat dan sedekah. Selama ini Madiyo banyak menyantuni fakir miskin, namun ia sendiri tidak tahu apakah itu masuk zakat atau sedekah. Yang jelas, menurut pengakuan Madiyo, yang ia berikan selama ini telah lebih dari sekedar zakat yang hanya 2,5\%. Bapak Madiyo ini selain aktif memberikan dananya ke lembaga zakat DSH, juga memiliki kelompok yang ia namakan dengan 
Laskar Sedekah, yang memiliki peran nyata di Klaten. Melalui Laskar Sedekah inilah santunan ia berikan, dan bahkan juga melibatkan banyak orang, melalui aksi solidaritas yang ia adakan bersama timnya (Madiyo, 27/2/2014). Jadi dapat disimpulkan bahwa Madiyo pun meskipun tidak terang-terangan mengatakan adanya alokasi dana zakat atau sedekah buat warga sekitarnya, tetapi ia ternyata melakukan kegiatan yang lebih dari sekedar sedekah biasa, dan itu untuk masyarakat yang berada di sekitarnya. Kegiatan itulah yang ia rintis bersama teman-teman lain, dan diberi nama dengan Laskar Sedekah.

Berdasarkan uraian di atas, dari pendalaman terhadap 70 muzaki yang berzakat ke lembaga zakat, ternyata semuanya merasakan pentingnya alokasi dana untuk warga sekitar yang dekat dengan mereka, baik kedekatan tersebut karena faktor kedekatan rumah atau kantor, maupun kedekatan karena hubungan darah. Pentingnya alokasi dana untuk warga di sekitar muzaki tersebut, diakui oleh dua jenis muzaki, yaitu: 1) muzaki yang menyatakan bahwa dirinya berzakat ke lembaga zakat tersebut, karena lembaga zakat tersebut menyantuni warga di sekitarnya; 2) muzaki yang menyatakan bahwa dirinya berzakat ke lembaga zakat tertentu, bukan karena lembaga zakat tersebut menyantuni warga di sekitarnya, karena warga di sekitarnya telah mereka berikan alokasi dana dari dana sedekah, atau dari sebagian besar persentase dana zakat yang diberikan kepada mustahik langsung.

\section{Kesimpulan}

Prospek lembaga zakat pada masa mendatang akan cenderung lebih baik. Hal ini setidak-tidaknya dapat dilihat dari pengetahuan muzaki tentang penyerahan zakat kaum muslimin pada masa Rasulullah s.a.w. yang cenderung lebih banyak menyatakan bahwa zakat pada masa Rasulullah s.a.w. itu diserahkan kepada pemerintah. Pemerintah itu pada masa sekarang itu dapat terwakili oleh lembaga zakat pemerintah maupun swasta. Pengetahuan tersebut tidak jauh berbeda dengan persepsi mereka. Menurut persepsi para muzaki, berzakat ke lembaga zakat tetap lebih afdhal dan lebih ideal. Namun demikian perilaku mereka menunjukkan bahwa yang mereka sukai adalah mengeluarkan zakat dengan dua model sekaligus, yaitu 
kepada lembaga zakat dan kepada mustahik langsung. Bahkan angka perilaku memilih dua-duanya ini cukup besar, yakni $54 \%$. Ini menunjukkan perilaku para muzaki yang cenderung moderat, mengambil jalan keluar win-win solution.

Selain itu kecenderungan muzaki lebih memilih lembaga zakat milik swasta dibandingkan lembaga zakat milik pemerintah, yakni sebesar 165 muzaki (57\%). Padahal itu dengan asumsi muzaki yang menyerahkan zakat ke masjid dikategorikan dalam kelompok tersendiri. Seandainya penyerahan zakat ke masjid juga dianggap sebagai lembaga zakat milik swasta, maka secara keseluruhan ada 187 muzaki (65\%) yang berzakat ke lembaga zakat swasta, dari total responden yang berjumlah 287 orang. Sedangkan yang berzakat ke lembaga zakat milik pemerintah hanya 39 orang (14 \%). Dan sebanyak 61 responden (21 \%) tidak menjawab. Oleh karenanya, saat ini belum tepat waktunya jika ada upaya dari pemerintah untuk menyatukan manajemen zakat menjadi satu dan dikelola pemerintah. Opini publik masih belum dapat dilepaskan dari kepercayaan terhadap lembaga zakat swasta, dibandingkan terhadap lembaga zakat pemerintah.

Solusi yang ditawarkan oleh para muzaki tentang pengelolaan zakat di Indonesia, menurut mayoritas dari mereka sebaiknya dikelola oleh satu lembaga zakat, hanya saja mereka tidak memilih apakah itu lembaga zakat swasta atau lembaga zakat pemerintah. Bahkan yang memilih agar pengelolaan zakat terfokus oleh satu pengelola, tanpa menyebutkan apakah itu pemerintah atau swasta, ada $46 \%$. Sedangkan yang memilih satu pengelola dan dari kalangan swasta, hanyalah $12 \%$. Lalu yang memilih satu pengelola dari kalangan pemerintah hanya $9 \%$. Meskipun demikian, dari hasil wawancara terhadap 396 responden, secara umum mereka tidak menolak jika pemerintah yang mengelola zakat, dengan catatan pemerintah bersikap adil dan amanah. Responden yang mensyaratkan pemerintah harus adil dan amanah dalam pengelolaan dana zakat ada 339 orang ( $85 \%)$.

Muzaki yang berzakat di lembaga zakat, lebih merasakan kepuasan ketika lembaga zakat tersebut menyantuni warga di sekitar tempat tinggal atau kantor muzaki. Karenanya, jika selama 
ini banyak muzaki yang mengalokasikan dananya ke mustahik langsung, maka itu adalah koreksi buat lembaga-lembaga zakat yang ada, khususnya terkait dengan distribusi zakat kepada warga, sebagai objek santunan. Santunan yang paling banyak dan sering dilihat secara langsung oleh muzaki adalah santunan pendidikan (34 \%), lalu santunan sosial (28\%), keagamaan (22\%), pemberdayaan ekonomi (9\%) dan kesehatan (7\%).

\section{Daftar Pustaka}

Abilawa, M. Sabeth. 2010. Gelombang Ketiga Peradaban Zakat dalam Republika, 6 Januari 2010.

Abu Yusuf. 1979. Kitabu al-Kharaj. Beirut: Daru al-Ma'rifah.

Ali, Mohammad Daud. 1988. Sistem Ekonomi Islam Zakat dan Wakaf. Jakarta: Penerbit UI. Cet. ke 1.

Al-Qardhawi, Yusuf. 1994. Fiqhu az-Zakah, Dirasah Muqaranah liAhkamiha wa Falsafatiha fi Dhau'i al-Qur'ani wa as-Sunnah. Kairo: Maktabah Wahbah, II:

Bisri, A. Zaini. 2012. Zakat, Program Besar yang Terbengkalai dalam Suara Merdeka, 12/8/2012.

Faridi, F. R. 1976. Zakat and Fiscal Policy dalam Studies in Islamic Economics, edited by Khurshid Ahmad, Leicester: The Islamic Foundation.

Geertz, Clifford. 1973. Religion as a Culture System, Interpretation of Cultures, Selected Essays, New York: Basic Books.

Harahap, Rachmad Faisal. 2013. Astaga RI Peringkat ke 64 untuk Pendidikan, dalam http://news.okezone.com/ $\mathrm{read} / 2013 / 06 / 01 / 373 / 816065 /$ astaga-ri-pringkat-ke-64-untukpendidikan, tanggal 1 Juni 2013, diakses pada tanggal 1 Juni 2015.

Inoed, Amiruddin, dkk. 2005. Anatomi Fiqh Zakat, Potret dan Pemahaman Badan Amil Zakat Sumatera Selatan, cet. ke-1, Yogyakarta: Pustaka Pelajar.

Jaelani, Ahmad, 2008. Pengaruh Kualitas Pelayanan dan Social Marketing Lembaga Amil Zakat (LAZ) terhadap Keputusan 
Berzakat Muzaki (Studi Kasus pada Rumah Zakat Indonesia), Tesis Program Studi Timur Tengah dan Islam, Program Pascasarjana, Universitas Indonesia.

Mus'ab, A. 2012. Pengaruh Religiusitas, Tingkat Penghasilan, dan Layanan terhadap Minat Muzakki untuk Membayar Zakat Maal di LAZIS NU, Tesis Program Pascasarjana UIN Yogyakarta.

Muthohar, Ahmad Mifdlol. 2015. Preferensi Perasaan Berkah dalam Kecenderungan Pilihan Berzakat ke Lembaga Zakat di Jalur Joglosemar, Disertasi Program Pascasarjana UIN Sunan Kalijaga, Yogyakarta.

Nasution, S. 1996. Metodologi Research Penelitian Ilmiah, Jakarta: Bumi Aksara.

Rama, Ali. 2010. Ekonomi Syariah dan Outlook 2011, Republika, 29/12/2010, dalam http://www.republika.co.id, diakses tanggal 4 November 2013.

Republika. 2013. Baznas: Potensi Zakat Nasional Rp 217 Triliun dalam http://www.republika.co.id/berita/ramadhan/kabarramadhan/11/08/19/lq6ibr-baznas-potensi-zakat-nasional-rp217-triliun, diakses tanggal 4 November 2013.

Supardi. 2005. Metodologi Penelitian Ekonomi dan Bisnis, Yogyakarta: UII Press, cet. ke-1.

Syaparuddin. 2011. Faktor-faktor yang Mempengaruhi Minat masyarakat melakukan pembayaran zakat melalui organisasi zakat, Disertasi Program Pascasarjana UIN Yogyakarta.

Wawancara dengan Noor Utami, Helmi dan Irfan (24/2/2014), Bambang, Samino dan Sofyan (26/2/2014), Madiyo (27/2/2014), Wiwik 1 dan Wiwik 2 (28/2/2014), Anita (1/3/2014), Abdul Basith (2/3/2014), Ifonilla Yeniati (19/4/2014), Aqni Hanifa dan Lutfi (20/4/2014), Ayu Intan, Agus, Yan Surono dan Wasdi (21/4/2014), Sadha, Fulan, Nisa' Puspitasari, Muharyati, dan Juz'an (22/4/2014).

Wawancara terhadap 70 responden muzaki yang berzakat ke lembaga zakat, semenjak tanggal 24 Februari 2014 hingga tanggal 23 April 2014, di sekitar wilayah karesidenan Yogyakarta, Surakarta dan Semarang. 